Review of Income and Wealth

Series $\bullet$, Number $\bullet, \bullet 2011$

\title{
PRODUCTIVITY GROWTH IN LATIN AMERICA OVER THE LONG RUN
}

\author{
By Pablo Astorga \\ Oxford Economics
}

AME R. Bergés

School of Advanced Study, University of London

AND

VALPy FitzGerald*

University of Oxford

\begin{abstract}
The low pace of Latin American productivity growth in recent decades, despite extensive economic reforms, has yet to be understood in a longer-run context where factors such as demographic changes, structural shifts, and investment levels can be taken fully into account. The OxLAD database provides comparable sectoral output and workforce series over 1900-2000 for the six leading economies in the region for the first time. Our analysis of this new dataset shows that: intersectoral resource reallocation reduced aggregate productivity growth in all three periods; total factor productivity growth was low throughout the century, and even negative in the closing three decades; and thus factor accumulationinvestment in fixed capital and skilled labor-was the main source of productivity growth in Latin America during the twentieth century.
\end{abstract}

JEL codes: O1, O4, N3, N5, N6

Keywords: aggregate productivity and growth, agriculture, manufacturing, total factor productivity, human capital

\section{INTRODUCTION}

Productivity — value added per head of economically active population, often referred to as "labor productivity"-more than quadrupled in Latin America during the twentieth century, yet did not converge toward that of industrial countries. Other regions such as Southern Europe and East Asia have evidently made considerably more progress, certainly since World War II. In contrast, Latin American productivity actually declined during the last quarter of the century, despite extensive economic reforms, leading to both heated debate among economic policy makers and extensive academic research as to the reasons.

The recent quantitative literature on productivity in Latin America has focused on the post-1970 period and addressed aggregate rather than sectoral productivity. ${ }^{1}$ By doing so, potentially important longer-term factors and trends

Note: We thank the Hewlett Foundation for research funding.

*Correspondence to: Valpy FitzGerald, Professor of International Development, St Antony's College, Oxford OX2 6JF, UK (edmund.fitzgerald@sant.ox.ac.uk).

${ }^{1}$ See Fajnzylber and Lederman (2000) and Paus (2003), for instance.

Review of Income and Wealth (C) 2011 International Association for Research in Income and Wealth Published by Blackwell Publishing, 9600 Garsington Road, Oxford OX4 2DQ, UK and 350 Main St, Malden, MA, 02148, USA. 


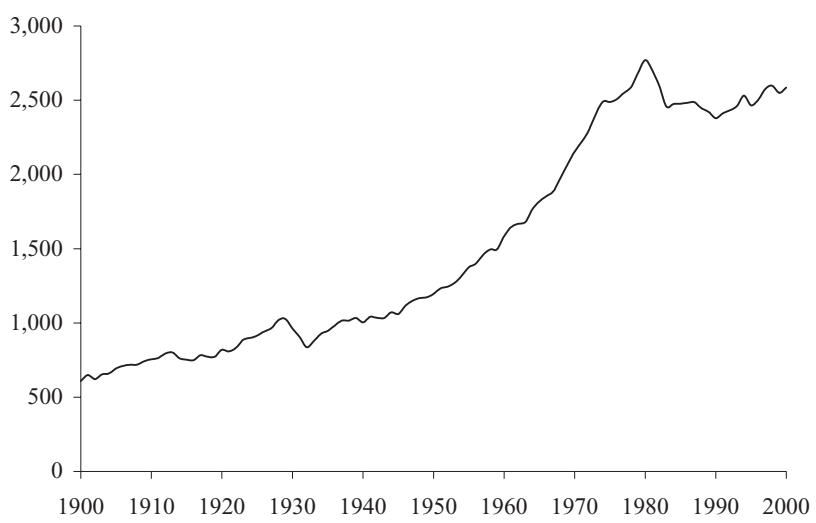

Figure 1. Productivity in the LA6 1900-2000 (1970 PPP\$ per EAP)

Source: Table A1.

appear to have been overlooked. However, new statistical series for the leading regional economies over the entire twentieth century from the Oxford Latin American Economic History Database (OxLAD), constructed from national sources on a comparable basis, now permit a more comprehensive long run analysis of aggregate and sectoral productivity change, total factor productivity growth, and factor accumulation in the region. ${ }^{2}$ The summary shown in Figure 1 thus reveals that recent trends are not typical of the century as a whole: the six leading economies in the region saw 1.3 percent per annum productivity growth between 1900 and 1936, followed by 2.3 percent in 1937-77 in contrast to zero growth for 1978-2000; the volatility of productivity growth fell from the first to the second period, only to rise again in the third. ${ }^{3}$

This paper is structured as follows. In Section 2 we explain how the three periods are identified and place the Latin American experience into global perspective. We then test three alternative explanations for the logistic shape of the long run productivity trend. The first, which we examine in Section 3, is that aggregate productivity change in the early stages of economic modernization was determined by the reallocation of labor from agriculture to manufacturing. In Section 4 we test the second hypothesis that differences in "total factor productivity" growth - reflecting both new technologies and institutional developmentswere the main determinants of the trends in output per worker. The third hypothesis, that the major determinant is factor accumulation (of fixed capital and skilled labor), is explored in Section 5 and turns out to be the most compelling. Section 6 concludes with a discussion of the implications of these results for possible lines of explanation for the evident low rates of factor accumulation and

${ }^{2}$ The OxLAD database is available at http://oxlad.qeh.ox.ac.uk/.

${ }^{3}$ The six leading economies in the region (the "LA6") are Argentina, Brazil, Chile, Colombia, Mexico, and Venezuela. These economies account for over three quarters of the output and population of the 20 Latin American republics. In the rest of Latin America the problem was even worse: 1950-2000 productivity growth averaged only 0.9 percent per annum, compared to 1.3 in the LA6. 
thus, in the last resort, of productivity. An Appendix (available online) includes notes on the estimation procedure of our productivity series as well as detailed tables and additional figures.

\section{Long-Run Productivity Trends}

Our estimates of aggregate productivity levels_-value added per economically active person at 1970 purchasing power parity (PPP) prices - show a clear process of convergence within Latin America during the twentieth century, as measured by the coefficient of variation across the leading six economies (see Table A1 in the Appendix). However, most of this convergence occurred in the first half of the century when variation halved; the gap fell by only a quarter in the second half. This was mainly due to productivity in Argentina, Chile, and Colombia rising more slowly than in Mexico, Brazil, and Venezuela, despite the "head start" of the former three over the latter in terms of capital, labor, and institutions. In other words, this intra-regional pattern conforms reasonably to that experienced among industrial nations (Baumol, 1986).

As we have already seen in Figure 1, the productivity growth pattern for the LA6 over the century clearly falls into three distinct periods. In this paper we have simply determined these by fitting a polynomial time trend by OLS and finding the points of inflexion in the growth trend (given by the roots of the second derivative) which turn out to be in 1936 and 1977. Astorga et al. (2005a) estimate autoregressive models for each country and test formally for structural breaks, showing almost identical dates for those common breaks, in addition to idiosyncratic breaks in particular countries (such as the Mexican revolution). This periodization also coincides with that used by authors such as Bulmer-Thomas (1994) and Hofman (2000), derived from shifts in policy regime, while having the advantage of being derived from the data itself. Therefore, while complete figures by decade are given in the Appendix (and all the data on OxLAD), in order to simplify exposition here we discuss long-run productivity trends divided into three periods: 1900-36, 1937-77, and 1978-2000.

The 1900-36 period, broadly characterized by primary-export led growth and limited state intervention saw a moderate productivity growth rate- 1.7 percent per annum - but considerable volatility (i.e. coefficient of variation) as we have seen. This outcome presumably reflects the exogenous impact of major world trade recessions in 1918 and 1929 as much as internal factors, while much of the productivity growth itself probably came from the exploitation of new natural resource reserves rather than increasing capitalization or technical progress. ${ }^{4}$ In contrast, the pace of productivity growth between 1937 and 1977-the so-called "import substitution" phase of state-led industrialization - was substantially faster at 2.5 percent per annum with lower volatility. Protected domestic markets and rapid urbanization appear to have stimulated investment and reduced exposure to external shocks, although the substantial price distortions meant that the transi-

${ }^{4}$ Export growth in the LA6 during 1900-36 was 5 percent per annum on average, but extremely volatile with a standard deviation of 16 percent, mainly due to world price fluctuations. In terms of trade shocks as an obstacle to growth during this period, see Cárdenas et al. (2001, chapter 1) and Thorp (1998, pp. 88-95). 
Review of Income and Wealth, Series $\bullet \cdot$, Number $\bullet \cdot, \bullet 2011$

TABLE 1

Productivity Trends in the LA6, 1900-2000

\begin{tabular}{lcccc}
\hline \hline & $1900-36$ & $1937-77$ & $1978-2000$ & $1900-2000$ \\
\hline Rate of growth (\%) & 3.2 & 5.6 & 2.8 & \\
GDP & 1.8 & 2.8 & 2.6 & 2.1 \\
EAP & 1.7 & 2.5 & 0.0 & 1.6 \\
Productivity & & & & \\
Volatility (\%) & 1.03 & 0.39 & 0.80 & 0.71 \\
GDP & 0.14 & 0.16 & 0.31 & 0.32 \\
EAP & 1.88 & 0.74 & 12.03 & 1.57 \\
Productivity & & & & \\
\hline
\end{tabular}

Notes: Volatility is defined as the ratio of the standard deviation of intra-period growth and mean intra-period growth.

Source: OxLAD (http://oxlad.qeh.ox.ac.uk/).

tion to industrial exports was not attained (FitzGerald, 2001, pp. 60-9). The extensive economic reforms in the 1978-2000 period were designed to reopen the Latin American economies and increase growth, yet productivity stagnated during this period and became more volatile. Macroeconomic instability arising from the debt crisis of the early 1980s and subsequent premature financial liberalization were clearly contributory factors, but the scale of market deregulation and increased income inequality were justified in terms of expected productivity gains - which did not in fact take place. ${ }^{5}$

Although this record is clearly intrinsically disappointing in terms of the evident need to generate higher incomes and overcome underdevelopment, only international comparison is objectively meaningful. One obvious comparator is the U.S., not only for its propinquity but also because it is the conventional benchmark used by Latin Americans. Growth theory would lead us to expect convergence of LA6 on U.S. productivity in the long run, under either the neoclassical model of diminishing factor returns or the endogenous growth model of technological diffusion and learning lags. However, as Figure 2 demonstrates, productivity in the LA6 failed to converge on the U.S., the former fluctuating around a stationary level of 17 percent of the latter during the whole twentieth century. The narrowing of the productivity gap in the 1930s is only apparent: the Great Depression had a far greater effective demand impact in the U.S. (Thorp, 1998). The subsequent catching up in the 1970s does appear to be real, reflecting high investment rates in Latin America as we shall show below, but was soon eroded as the U.S. entered its technology-based boom and Latin America suffered repeated macroeconomic crises toward the century's close.

Figure 2 also shows a comparison with Spain, as representative of Southern Europe. During our first period (1900-36) there was no convergence, with LA6 productivity remaining at about one-third of the Spanish level. In the second period (1937-77) the ratio does rise to more than one-half, but this is due as much to the consequences of civil war and autarky in Spain as to rapid industrialization in Latin America. In the third period the productivity gap falls back below that of

${ }^{5}$ The reasons why these reforms did not lead to greater productivity are extensively discussed in Paus (2003) and Fajnzylber and Lederman (2000). 


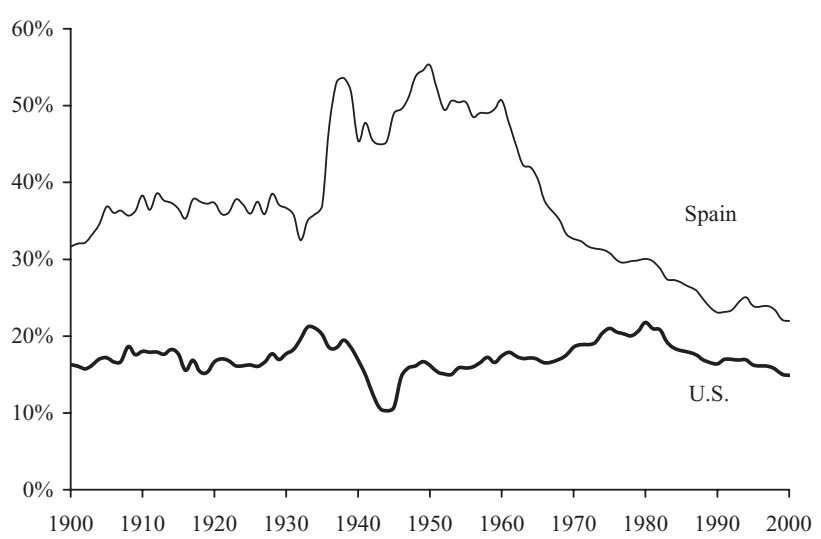

Figure 2. Ratio of LA6 Productivity to Spain and U.S. Productivity (\%)

Source: Figure 1; U.S. and Spanish GDP at PPP prices from Maddison (1995), updated with data from IMF (2002) and rebased to 1970; Spanish EAP calculated from Prados de la Escosura (2003); U.S. EAP from Department of Commerce (1949) and ILO (2002).

the opening of the century, as the Spanish economy integrates to the European Union and its productivity converges on that of the U.S. This comparison underlines the scale of the Latin American "missed opportunity" of progressing from the initial stages of protected industrialization toward international competitiveness.

\section{Sectoral Productivity and Structural Change}

The first logical step in attempting to explain the Latin American productivity record during the twentieth century is to disaggregate total productivity by sector. The classical "Kuznets" assumptions are that industrial productivity is higher than that in agriculture, and that the former grows faster than the latter. As labor is reallocated from one sector to the other, one would expect productivity growth to rise. In addition, the existence of surplus rural labor (in the sense that marginal product is lower than average income) means that migration to the towns will raise average agricultural productivity even without further investment or new technology. Finally, in the initial "extensive" stage of industrialization, employment should grow rapidly and productivity expand less than manufacturing output; while in the subsequent "intensive" stage industrial employment should grow more slowly and productivity accelerate.

The OxLAD database has sufficient data on the labor force and value added in agriculture and manufacturing for the LA6 to estimate productivity (i.e. output per worker) in these two sectors over the entire century. Unfortunately, although we can estimate the aggregate capital stock (see the next section) we cannot do this by sector. ${ }^{6}$ Output per worker in mining is also available, but this metric reflects ongoing resource discovery and shifting international demand patterns, rather than labor productivity as such, so we omit this sector - which in any case employs

${ }^{6}$ The only comparative source for manufacturing and agriculture capital stock is Crego et al. (1998), but this only covers Chile, Colombia, and Venezuela during 1967-92. 
Review of Income and Wealth, Series $\bullet \cdot$, Number $\bullet \cdot, \bullet 2011$

TABLE 2

Sectoral Productivity Growth Rates 1900-2000

\begin{tabular}{lccccccc}
\hline \hline & \multicolumn{3}{c}{ Agriculture } & & \multicolumn{3}{c}{ Manufacturing } \\
\cline { 2 - 3 } & Output & Employment & Productivity & & Output & Employment & Productivity \\
\hline Argentina & 2.3 & 0.7 & 1.5 & & 3.5 & 1.9 & 1.6 \\
Brazil & 3.3 & 1.5 & 1.8 & & 5.3 & 2.7 & 2.5 \\
Chile & 2.1 & 0.7 & 1.3 & & 3.9 & 1.6 & 2.3 \\
Colombia & 3.4 & 0.8 & 2.6 & & 5.2 & 2.8 & 2.4 \\
Mexico & 2.3 & 0.8 & 1.5 & & 5.4 & 2.4 & 2.9 \\
Venezuela & 3.5 & 0.7 & 2.8 & & 5.6 & 3.0 & 2.5 \\
LA6 & 2.9 & 1.1 & 1.8 & & 5.0 & 2.5 & 2.5 \\
\hline
\end{tabular}

Notes: "LA6" is population-weighted mean.

Source: OxLAD.

a very small share of the workforce. Services present a different problem: while they account for over half of output and employment in the LA6 from 1945 onwards, their ratio can be misleading. On the one hand, "output" in the government sector has little economic meaning ("productivity" is no more that the average civil service salary); while on the other, petty commerce and services act as "labor sponges" with much of their workforce underemployed - so that "productivity" trends reflect migration rather than efficiency or capitalization. ${ }^{7}$

Our measure of sectoral productivity $\left(P_{j t}\right)$ in sector $j$ in year $t$ is aggregate labor productivity $\left(P_{\Sigma}\right)$ in 1970 PPP dollars multiplied by the share $\left(X_{j}\right)$ of that sector in GDP in 1970 PPP dollars and divided by its share in the $\operatorname{EAP}\left(Z_{j}\right)$ :

$$
P_{j t}=P_{\Sigma t} \frac{X_{j t}}{Z_{j t}} .
$$

The individual components $(X, Z)$ are shown in the Appendix, Table A3. The results for LA6 sectoral productivity growth are summarized in Table 2; sectoral growth rates by decade and country are given in the Appendix, Table A4.

Output, employment, and productivity in manufacturing grew faster than in agriculture over the century as a whole for all countries except Colombia and Venezuela, where the two rates were roughly equal. For the LA6 as a whole, productivity growth in agriculture over the century was nearly three-quarters of that in manufacturing; which implies that both the latter was lower and the former was higher than theory would anticipate.

However, the sectoral productivity gap did widen over the course of the century: productivity in LA6 manufacturing was only 1.5 times than in agriculture in 1900, but nearly three times greater in 2000 (Appendix, Table A3). This was mainly due to the gap widening in Brazil, Chile, and Mexico: because not only was the 1900 gap narrowest in Argentina and Colombia and remained stable over the century; but also in Venezuela the gap actually narrowed. However, it should be

${ }^{7}$ See FitzGerald (1993, chapter 5), who provides a model of apparent productivity in the urban informal sector based on inward migration to towns in response to demand for petty services generated by the formal sector, forcing down marginal urban income until it approximates average rural income at equilibrium. 
remembered that: first, much of the increase in agricultural productivity is in fact the result of rural-to-urban migration of surplus rural labor; and second, technological transfer from abroad (principally the U.S.) into "modern" agriculture has been less difficult than the more complex technological learning in manufacturing, which has required new forms of corporate organization as well as imported equipment and labor skilling (Martin and Mitra, 2001). ${ }^{8}$ This may also explain why long run growth in agriculture has been steadier than in manufacturing.

As we have seen, aggregate productivity growth was significantly higher and more stable during 1937-77 than in the previous period, after which it became more volatile and slowed down. As might be expected, manufacturing productivity not only varies less than agriculture between countries but also shows a stronger regional convergence trend over the century. Agricultural productivity continued to grow after 1977 in Brazil and Chile, but declined in Mexico and Argentina, and more dramatically in Colombia and Venezuela. Overall, however, agricultural productivity seems to have increased relatively rapidly and steadily between the mid-1950s and the mid-1980s, due partly to labor shedding but also to the spread of irrigation and "green revolution" technologies. The pattern of manufacturing productivity growth is similar, with more rapid growth during 1937-77 followed by decreases in all countries in the 1980s and some improvement in the 1990s in all countries except Mexico.

These patterns of sectoral productivity change (see Figure A1 in the Appendix) were underpinned by changes in the composition of national output and employment. As Table A3 in the Appendix shows, agricultural employment in the LA6 declined from about 61 percent of the economically active population in 1900 to 16 percent by 2000 , the steepest fall being during $1937-77$. However, significant rural-to-urban migration only began in the 1950s and the absolute size of the labor force in agriculture in the LA6 did not start to decline until the 1980s. ${ }^{9}$ In contrast, the share of manufacturing in total EAP remained stable at 14 percent between 1900 and 1936, rising to a mid-1970s peak of 17 percent, and falling back again to 15 percent in 2000 as trade liberalization and industrial restructuring took effect. In other words, the effect of rural-urban migration was not mainly to increase the industrial labor force but rather to swell the ranks of the urban service sector. Specifically, of the 45 percentage-point fall of the agricultural labor force as a share of EAP over the century, only 3 percentage points had entered the industrial labor force at its peak at the end of the second period.

Table A3 also illustrates the sharp fall in the agriculture share of output over the century, with the middle decades seeing the greatest decline. In contrast, the manufacturing share of output followed a similar pattern to that of its employment share, rising gradually from 9 percent in 1900 to 13 percent in 1936, but then shifting rapidly upwards to 23 percent by 1977 before falling back to 20 percent in 2000. In other words, the relative positions of the two sectors were interchanged over the century; as industry took over from agriculture as the main engine of growth.

${ }^{8}$ Unfortunately Martin and Mitra only include Chile, Colombia, and Venezuela in 1967-92; but they show that this pattern is common in middle-income developing countries.

${ }^{9}$ This rural exodus occurred much later in Mexico because it was the only major Latin American country to carry out a major redistributive land reform. 
Review of Income and Wealth, Series $\bullet \cdot$, Number $\bullet \cdot, \bullet 2011$

TABLE 3

Sectoral Contribution to Aggregate Productivity (\%)

\begin{tabular}{|c|c|c|c|c|c|c|c|c|c|c|c|c|}
\hline & \multicolumn{4}{|c|}{$1900-36$} & \multicolumn{4}{|c|}{$1937-77$} & \multicolumn{4}{|c|}{$1977-2000$} \\
\hline & Tot & Agr & Ind & Rest & Tot & Agr & Ind & Rest & Tot & Agr & Ind & Rest \\
\hline Argentina & 1.30 & 0.37 & 0.20 & 0.73 & 1.50 & 0.63 & 0.49 & 0.38 & 0.30 & -0.03 & 0.26 & 0.07 \\
\hline Brazil & 1.50 & 0.71 & 0.11 & 0.68 & 3.30 & 1.57 & 0.29 & 1.44 & 0.20 & -0.28 & 0.14 & 0.34 \\
\hline Chile & 1.60 & 0.50 & 0.23 & 0.88 & 1.20 & 0.79 & 0.37 & 0.05 & 2.00 & 0.33 & -0.06 & 1.73 \\
\hline Colombia & 2.70 & 1.84 & 0.25 & 0.62 & 2.20 & 2.16 & 0.35 & -0.31 & -0.10 & -0.20 & 0.12 & -0.02 \\
\hline Mexico & 1.50 & 0.31 & 0.06 & 1.13 & 2.70 & 3.31 & 0.29 & -0.91 & 0.00 & 0.15 & 0.03 & -0.18 \\
\hline Venezuela & 3.70 & 2.12 & 0.35 & 1.24 & 3.40 & 3.13 & 0.37 & -0.10 & -2.40 & -0.63 & -0.04 & -1.73 \\
\hline LA6 & 1.70 & 0.82 & 0.19 & 0.70 & 2.50 & 1.90 & 0.35 & 0.24 & 0.00 & -0.08 & 0.13 & -0.05 \\
\hline
\end{tabular}

We can now attempt to answer the question: to what extent can aggregate productivity change in Latin America be explained by differences in sectoral productivity growth and the intersectoral reallocation of labor? We have seen that in fact the patterns of productivity growth over time in agriculture and manufacturing were broadly similar over the century, and these two trends in themselves clearly explain much of the pattern in aggregate productivity change discussed in the previous section, with acceleration from the first to the second period and stagnation thereafter. This contribution $(c)$ of each sector to aggregate productivity growth is measured in Table 3 and is defined as the product of EAP share $\left(Z_{j}\right)$ at the beginning of each period $(\tau)$ and productivity growth $\left(p_{j}\right)$ in the sector $(j)$ for the period:

$$
c_{j \tau}=Z_{j \tau} \cdot p_{j \tau} \cdot
$$

It is immediately clear that productivity growth within agriculture and industry is the main cause of aggregate productivity growth. However, while agriculture dominates in the first third of the century as might be expected, it continues to do so in the second because industry is still a much smaller proportion $(Z)$ of the labor force. Thus, although its own productivity growth rate $(p)$ is higher, its overall contribution $(c)$ is less. ${ }^{10}$ So, the fact that both agricultural and industrial productivity growth slow down in the last period is the main cause of the disappointing record in those final decades.

As we have noted above, the labor force reallocation effect in Latin America during the twentieth century is to swell the labor force in the "rest" of the economy - that is, services and commerce. Clearly productivity growth has taken place as parts of the service sector such as banks and transport have modernized (Mulder, 2002) but this is counterbalanced by the expansion of petty commerce (e.g. street sellers) in most cases. Only in three out of eighteen "country periods" does this conclusion not hold: but in Venezuela 1900-36 and Brazil 1937-77 this is because the main rural-urban migratory flood (and thus the expansion of the informal sector) is relatively late; and only in the case of Chile 1978-2000 can we

\footnotetext{
${ }^{10}$ The same is true to an even greater extent of the mining sector, because although productivity is clearly relatively high, a very small fraction of the labor force is employed.
} 
see an unambiguous case of tertiary productivity growth - which in fact is the major cause of the exceptional aggregate performance of Chile in this period.

In sum, it is clear that intersectoral labor reallocation in the classical KuznetsLewis model is not the main source of productivity growth in Latin America during the twentieth century, with the possible exception of Chile. We provide further econometric support for this result in Astorga (2010) in the context of a two-equation growth system. This allows for testing for the conditional productivity effect of structural change (measured by the share of agriculture in total value added). We found little evidence supporting a significant role of sectoral reallocation once other growth factors such as capital accumulation (both physical and human) and macroeconomic stability are taken into account.

\section{Total Factor Productivity Growth}

The second explanatory hypothesis is that the evident differences in productivity growth over the century are the result of changes in "total factor productivity" (TFP) growth. Accounting for that part of output growth unexplained by the accumulation of factor stocks as such, TFP should capture not only the contribution of endogenous or imported technical progress but also that of institutional developments - whether positive or negative. ${ }^{11}$ TFP growth is usually estimated as the so-called "Solow residual" in a simple growth accounting framework where the factor contributions are estimated using a constrained Cobb-Douglas production function and the key parameter is the labor share in GDP. ${ }^{12}$ Despite serious limitations, this method is still widely used because it allows TFP growth estimates to be made for relatively short periods, albeit at the cost of ignoring cyclical influences. ${ }^{13}$

Table 4 summarizes the results of the main growth accounting exercises for Latin America to date. Because they use different periods and country groups these estimates cannot be compared in detail. Nonetheless they provide a consistent picture of minimal TFP growth over the second half of the century: modest yet positive during the post-war decades, followed by decline in the 1980s and a subsequent recovery in the early 1990s. In the most comprehensive growth accounting study of Latin America to date, using "augmented" factor stocks, Hofman (2000) finds that for 1950-96 the contribution of TFP to GDP growth in Latin America was lower than that for OECD countries and substantially less than in the "newly industrializing countries" of East Asia. ${ }^{14}$ Bruton $(1967,1995)$ argues

\footnotetext{
${ }^{11} \mathrm{~A}$ well-known debate continues over the extent to which output growth in developing countries should be attributed to TFP growth on the one hand (see Dahlman et al., 1987; Romer, 1993) or to factor accumulation (see or Young, 1994, 1995; Collins and Bosworth, 1996) on the other. Our results support the latter view.

${ }^{12}$ That is, where the exponents are assumed to sum to unity. In a production function $Y=A K^{1-\beta} L^{\beta}$, TFP is $A$ and its growth rate (a) is given by $a=y-[(1-\beta) k+\beta l]$ so only the labor share $(\beta)$, and the rates of growth of GDP $(y)$, capital stock $(k)$ - often replaced by the investment rate - and the labor force $(l)$ need be available.

${ }^{13}$ Briefly, the limitations are due to the implausibility of assumptions on competitive factor markets, full capacity utilization of labor and capital, and constant returns to scale in developing countries. In addition, the labor shares under-report the informal sector.

${ }^{14} \mathrm{Hofman}(2000)$ adjusts fixed capital stocks to reflect age and composition, and the labor force for years of schooling.
} 
Review of Income and Wealth, Series $\bullet \cdot$, Number $\bullet, \cdot \bullet 2011$

TABLE 4

Previous Total Factor Productivity Growth Estimates for Latin America

\begin{tabular}{|c|c|c|c|c|}
\hline \multirow[b]{2}{*}{ Bruton $(1967,1995)$} & \multirow{2}{*}{$\begin{array}{l}\text { Countries in } \\
\text { Study (no.) } \\
5\end{array}$} & \multicolumn{3}{|c|}{$\begin{array}{c}\text { TFP Growth (\%) } \\
\text { (years covered in study) }\end{array}$} \\
\hline & & $\begin{array}{c}1.4 \\
(1940-64)\end{array}$ & $\begin{array}{c}-0.2 \\
(1961-88)\end{array}$ & \\
\hline De Gregorio (1991) & 12 & $\begin{array}{c}1.3 \\
(1950-70)\end{array}$ & $\begin{array}{c}0.3 \\
(1970-85)\end{array}$ & \\
\hline Elías (1992) & 7 & $\begin{array}{c}1.5 \\
(1940-80)\end{array}$ & $\begin{array}{c}-2.3 \\
(1980-85)\end{array}$ & \\
\hline Fajnzylber and Lederman (2000) & 18 & $\begin{array}{c}0.7 \\
(1950-79)\end{array}$ & $\begin{array}{c}-1.7 \\
(1980-89)\end{array}$ & $\begin{array}{c}1.1 \\
(1990-95)\end{array}$ \\
\hline Hofman (2000)-1 & 6 & $\begin{array}{c}1.8 \\
(1950-80)\end{array}$ & $\begin{array}{c}-0.9 \\
(1980-89)\end{array}$ & $\begin{array}{c}1.8 \\
(1989-94)\end{array}$ \\
\hline Hofman (2000)-2 & 6 & $\begin{array}{c}0.8 \\
(1950-80)\end{array}$ & $\begin{array}{c}-1.8 \\
(1980-89)\end{array}$ & $\begin{array}{c}1.0 \\
(1989-94)\end{array}$ \\
\hline
\end{tabular}

Notes: Period intervals are given in parenthesis. Hofman (2000)-1 refers to unaugmented TFP. Hofman (2000)-2 refers to doubly-augmented TFP.

Source: Bruton (1967, p. 1103), Bruton (1995, p. 15), De Gregorio (1991, p. 15), Elías (1992), Fajnzylber and Lederman (2000, p. 18), Hofman (2000, p. 113).

that even the relatively high 1940-64 rate was low by international standards and reflected a failure to adapt and modify diffused technologies. He attributes the subsequent decline in TFP rates to the exhaustion of the traditional development model in Latin America, well before the debt crisis. De Gregorio (1991), in contrast, associates low TFP rates with periods of low GDP growth and argues this is evidence of poor macroeconomic policy and political instability affecting fixed investment and technical innovation. Improved TFP rates in the period 1990-95 are linked by Fajnzylber and Lederman (2000) and the other authors with market liberalization, although subsequent events indicate that this was in fact a shortlived foreign portfolio investment boom.

Here we present what appear to be the first published estimates of total factor productivity for Latin America over the whole twentieth century. The first step in our approach is to define an aggregate production function for each of the LA6 of the form:

$$
Y_{t}=A_{t} K_{t}^{\alpha}\left(h_{t} L_{t}\right)^{\beta},
$$

where $Y$ is GDP in 1970 PPP dollars in each year $(t), K$ is the stock of fixed capital, and $L$ is the stock of labor, given by the economically active population and adjusted for quality changes by the literacy rate of the population $(h) \cdot{ }^{15} A$ is then total factor productivity (TFP). A significant innovation in this paper is the use of augmented labor in long-run historical data. Human capital stock is generally incorporated into econometric growth estimations for developed countries by using indicators of educational attainment or at least average years of schooling

\footnotetext{
${ }^{15} \mathrm{We}$ opted not to adjust for recession years, when capital and labor are under-used, as there is no satisfactory means of identifying the source of depressed demand (see North, 1993; Crafts and Mills, 2001; Easterly and Levine, 2001). Labor quality and quantity are conventionally taken to be perfect substitutes (see Barro and Sala-i-Martín, 1995).
} 
(Barro and Lee, 2000). For developing countries without such data, the proportion of children enrolled in secondary school is the usual replacement (Mankiw et al., 1992). Because even the latter statistic does not exist for Latin America for the whole century, we follow Romer (1990) and use literacy as our metric for the quality of the labor force. ${ }^{16}$

Data on the stock of capital for Latin American countries is not available from official sources so we have estimated it from annual figures for gross fixed capital formation by the "perpetual inventory" method (Goldsmith, 1951). ${ }^{17}$ The capital stock $\left(K_{t}\right)$ is defined as the sum of past net investment flows:

$$
K_{t}=K_{t-1}(1-\delta)+I_{t},
$$

where $I_{t}$ is gross fixed capital formation and $\delta$ is the annual depreciation rate, which we assume is 3.3 percent. Opening capital stock $\left(K_{0}\right)$ is estimated by applying a tentative capital-output ratio of 2 to GDP in 1900, which is then adjusted recursively. As disaggregated data on machinery, equipment, and residential and non-residential structures are not available for the whole century, we were unable to calculate the average age of the stock to reflect "vintage" effects. ${ }^{18}$ Capacity utilization remains a problem: Fajnzylber and Lederman (2000) simply disregard years of negative GDP growth; but Bruton (1967) points out that excess capacity may be a key factor in explaining productivity growth. In our case, as we are averaging TFP growth over relatively long periods, the cyclical effects should be much less.

The production function in log-linear form is estimated by OLS regression of the two factor stocks on GDP. ${ }^{19}$ From the logarithmic expression of (4) we have an estimation equation for the contribution of the two stocks over the whole century for each country $(n)$ :

$$
\ln Y_{n t}=C_{n}+\alpha_{n} \ln K_{n t}+\beta_{n} \ln \left(h_{n t} L_{n t}\right)+\varepsilon,
$$

where the intercept $\left(C_{n}\right)$ is a country-specific fixed effect. Estimation yields the two factor stock coefficients $\alpha$ and $\beta$ directly, while the goodness of fit indicates the extent to which GDP is "explained" by changes in these stocks. The full results and diagnostics are set out in the Appendix, Table A5. In all six cases the regression coefficients indicate that the two factor stocks explain all but a few percent of total GDP during the period; and thus that the net contribution of TFP growth for the century must be quite small. All the fits are very good, and the capital and labor coefficients are significant at the 1 percent level and of the expected sign, with the exception of labor for Venezuela ("Venezuela-1" in Table A5). However, con-

\footnotetext{
${ }^{16}$ See next section. The share of the region's population classed as literate in 1900 was 33 percent; by 2000 , it had risen to 89 percent. The workforce was also far healthier: life expectancy rose from 29 to 70 years over the century (see Astorga et al., 2005b).

${ }^{17}$ Note that TFP estimates are sensitive to these values (Pritchett, 1996).

${ }^{18}$ Hofman (2000) is the only source to do this, but only for the $1950-96$ period. The result of "augmenting" capital is this way is to reduce the resulting Solow Residual estimate of TFP growth - as Table 4 demonstrates. If we had been able to do this for the whole century, it would have strengthened our argument further.

${ }^{19}$ In contrast to De Gregorio (1991) and Fajnzylber and Lederman (2000), our approach makes no a priori assumptions regarding returns to scale.
} 
TABLE 5

Period Averages of TFP Growth $(\%)$

\begin{tabular}{|c|c|c|c|c|c|c|c|c|}
\hline \multirow[b]{3}{*}{ Coefficients } & \multicolumn{8}{|c|}{ TFP Growth } \\
\hline & \multicolumn{2}{|c|}{ 1900-2000 } & \multicolumn{2}{|c|}{$1900-36$} & \multicolumn{2}{|c|}{$1937-77$} & \multicolumn{2}{|c|}{ 1978-2000 } \\
\hline & Estimated & Standard & Estimated & Standard & Estimated & Standard & Estimated & Standard \\
\hline Argentina & 0.12 & -0.15 & -0.33 & -1.13 & 0.57 & 0.72 & 0.04 & -0.08 \\
\hline Brazil & 0.51 & -0.21 & 0.64 & 0.36 & 1.29 & 1.27 & -1.00 & -3.55 \\
\hline Chile & 0.47 & -0.29 & -0.41 & -2.20 & 0.43 & -0.44 & 1.19 & 1.27 \\
\hline Colombia & 0.61 & -0.01 & 1.20 & 1.87 & 0.83 & 0.10 & -0.82 & -3.30 \\
\hline Mexico & 0.09 & -0.15 & 0.06 & -0.05 & 0.56 & 0.79 & -0.78 & -2.15 \\
\hline Venezuela & 0.35 & -0.34 & 1.53 & -0.78 & 0.83 & 0.70 & -2.31 & -0.87 \\
\hline LA6 & 0.28 & -0.13 & 0.13 & -0.19 & 1.02 & 0.53 & -0.85 & -1.24 \\
\hline
\end{tabular}

Notes: Based on gross fixed capital stock estimates with initial capital-output ratio of 2 and depreciation rate of $3.3 \%$ and capital and labor elasticities reported in Table A5 in the Appendix. Calculated as compound annual growth rate of TFP estimates.

Source: Tables A4 and A5 in the Appendix.

straining the coefficients to non-negative values ("Venezuela-2") still gives an excellent fit. The DW statistics are all low due to autocorrelation between the residuals, as might be expected, but the F-statistics are all reassuringly high.

For all six countries the sum of the capital and (augmented) labor coefficients is close to unity-indicating few if any overall scale economies: this is consistent with convention but nonetheless surprising over the long run. ${ }^{20}$ The factor coefficients for Argentina, Brazil, Chile, and Mexico fall within the conventional range. However, Colombia and Venezuela have coefficients that are rather high for capital and low for labor. For Venezuela this might be explained by oil dependence, but Colombia is difficult to understand. Substituting the factor stock coefficients from the regression results back into equation (4) and taking the anti-log yields TFP estimates. Our resulting estimates of TFP growth rates for the three periods are reported in Table 5. ${ }^{21}$ For comparison, Table A6 in the Appendix shows estimates using the conventional coefficient values: these seem less convincing than ours, but tell a similar story.

TFP growth for the LA6 over the century as a whole was 0.3 percent per annum, which explains less than one fifth of observed productivity growth. However, the three periods are very different: in the 1900-36 period TFP growth was only 0.1 percent, rising to 1.0 percent in the middle $1937-77$ period. In fact,

\footnotetext{
${ }^{20}$ Long-run estimates for developed countries find returns to scale that are roughly constant, with a capital coefficient of the order of 0.4 (see Fischer, 1993; Nehru and Dareshwar, 1993); but Collins and Bosworth (1996, p. 155) suggest that the elasticity of capital should be higher in developing countries, and endogenous growth theory implies that increasing returns to scale are expected too.

${ }^{21}$ The comparison of average TFP growth rates calculated using the coefficients produced from the regressions reported in Table A5 and estimates based on more "standard" capital and labor coefficients of 0.35 and 0.65 suggest that the latter results in overestimated TFP in Argentina, Brazil, and Colombia in 66 percent of cases, in Chile and Mexico in 45 percent of cases, and in Venezuela in 36 percent of cases. For the LA6 aggregate, the conventional factor coefficients overstated TFPs for all periods; the gap in TFP estimates was greatest in the 1940s and 1950s and narrowest in the 1930s and 1980s. See Appendix Tables A7(A) and A7(B).
} 
in this middle period TFP explains 41 percent of productivity growth: as we shall see below, this is related to rising capital intensity - as in the case of industrial economies (Wolff, 1991) - and thus probably to embodied technological progress. TFP growth is actually negative in the last two decades of the century, and its inter-period fall accounts for more than 70 percent of the decline in productivity growth between the middle and the last period. Data available on capital imports give support to the role of embodied technology in explaining this contrasting outcome. The average annual rate of growth of imported capital (at constant prices) for the LA6 as a whole during the period 1945-77 was 8.6 percent, compared to 2.2 percent in the period 1978-2000; and the corresponding average ratio of imported capital to GDP for the group was 7.5 percent versus 5.2 percent, respectively.

Turning to the individual countries: in the first period, TFP growth clearly varies a great deal, doubtless due to the effect of the commodity cycle, and thus the volatility of resource rents; ${ }^{22}$ in the second period, TFP growth increases in all cases except Colombia and Venezuela; in the third only Chile - the "star reformer" of the period - showed significant TFP gains and the rest none or losses. Our two main conclusions from these results are: first, that the rapid rise of aggregate and sectoral productivity during 1937-77 was accompanied by relatively high rates of TFP growth as would be expected under the "embodiment" hypothesis, ${ }^{23}$ and second, that the structural adjustment efforts of the 1980s clearly did not lead to the expected efficiency gains except in the case of Chile - and here only at an enormous social cost.

In sum, these TFP growth rates are very low and, overall, explain little the observed productivity change. They are also consistent with earlier estimates in the literature for the second half of the century. Theory would predict that those Latin American countries with higher incomes and more advanced institutions at the outset of the century (such as Chile and Argentina) should experience higher TFP growth due to their ability to incorporate technology from industrialized countries faster and better. ${ }^{24}$ But Chile performs worse than Brazil-a relative latecomerover the whole century, while Argentina is the worst performer in the region. In the middle period when TFP growth in the region is fastest, Brazil, Mexico, and Venezuela have the best record: possibly because they were undergoing deep and rapid institutional change.

\section{Factor Accumulation and Productivity Growth}

We now turn to our third explanation. The hypothesis that the accumulation of factor stocks - fixed capital in particular - is the main cause of productivity growth in Latin America over the twentieth century has already been implied by the findings of the previous section of this paper. We must now analyze this factor accumulation process in more detail. Investment (gross fixed

\footnotetext{
${ }^{22}$ Unfortunately, we have no means of measuring the natural resource stock. Maddison (1995) uses total land area; but this is largely time invariant and ignores agricultural fertility and mineral resources.

${ }^{23}$ Solimano (1996) associates relatively high TFP growth in Argentina, Brazil, and Mexico in the 1940 s and 1950 s to import substitution and state-led industrialization.

${ }^{24}$ See Grossman and Helpman (1994) and Collins and Bosworth (1996).
} 


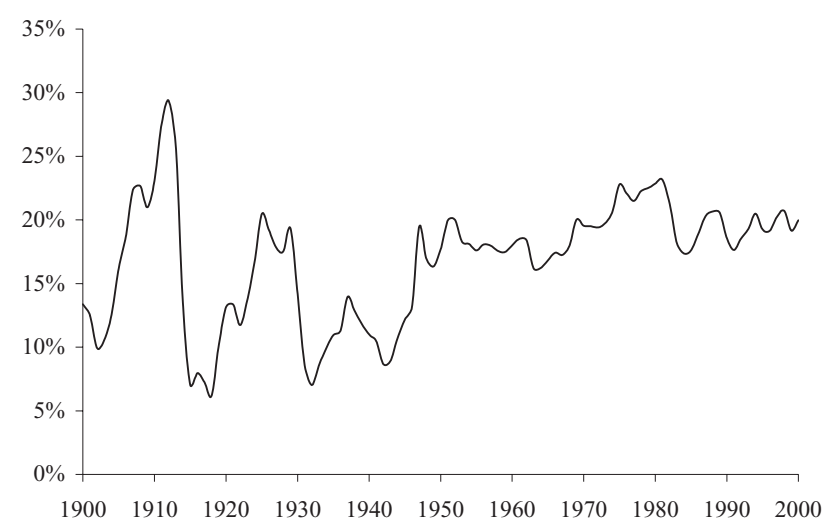

Figure 3. Investment Share of GDP in Latin America (\%)

Note: Population-weighted ratio of gross domestic fixed investment to GDP for the LA6. Source: OxLAD (http://oxlad.qeh.ox.ac.uk/).

capital formation) is required for the replacement of old stock, expansion of production, and embodiment of new technologies. Figure 3 shows how the investment rate-including both public and private-has evolved (see also Appendix, Table A8).

The high volatility and the decreasing trend during the first 1930-36 period reflect the cumulative effect of the post-World War I world trade recession and Great Depression itself on natural resource firms and their suppliers; followed in each case by domestic demand expansion into existing non-traded capacity (FitzGerald, 1984). In the second period, the investment rate rises and volatility decreases between 1937 and 1977, albeit with a severe dip during World War II due to capital goods scarcities, as the industrialization process based on protected domestic markets got underway. After 1978, with the negative effect of the 1982 debt crisis on investor expectations and the cumulative effect of financial and trade reforms, the investment rate appears to have followed a downward trend.

As Table A8 in the Appendix indicates, all six countries follow a broadly similar pattern, although their investment rates differ. If we compare the rate of investment in Latin America as a whole with that of East Asia for the period when comparable data is available, then the problem becomes clear: the average investment rate (gross fixed capital formation as a proportion of GDP) in 1960-77 was 21 percent in Latin America, and a similar 22 percent in East Asia; but in 19782000 while the rate in Latin America was again 20 percent, it had risen to 30 percent in East Asia, as this region moved from extensive to intensive industrialization and from domestic to export markets. ${ }^{25}$

The level of investment, net of depreciation, generates changes in the capital stock: for our purpose of explaining productivity change, we are interested in

${ }^{25}$ These data are from the World Bank World Development Indicators database. 
capital stock per worker. ${ }^{26}$ As Figure A2 and Table A11 in the Appendix indicate, capital per worker in the LA6 did not increase significantly between 1900 and 1950, but then rose rapidly - more than threefold between the 1950s and the 1980s-but declined thereafter. This seems to be consistent with the pattern of productivity growth and industrialization discovered above; the delayed turning point in the 1950s being due to better use of installed capacity in the 1930s and 1940s. The large increase in capital per worker between 1950 and 1980 also helps explain why this is also the only period with significant TFP growth, although the reliance on imported capital goods may also explain why this growth was so modest. The average ratio of capital goods in total imports was 0.6 in the period 1945-77, compared to 0.4 in the period 1978-2000. Two countries do show significant variations: Chile with a decline of capital stock per worker between 1970 and 1985, due to internal conflicts, but sustained and rapid growth thereafter; and Mexico with a rising trend right the way through from 1940 until the financial crisis of the mid-1990s. However, Colombia, Argentina, and Brazil show no increase between 1980 and 2000 at all, while Venezuela shows a marked decline.

The workforce in Latin America itself grew in response to population expansion and changes in participation rates, with improvement in its skill level as a result of the spread of schooling. Population growth in Latin America during the twentieth century reflects a familiar demographic transition, rising mid-century with the fall in mortality rates, and declining toward the end with the fall in birth rates (del Popolo, 2001). In addition, the increasing education of the workforceexpressed by the proportion of the adult population considered literate as shown in the Appendix, Table A9-clearly increased its productivity: indeed, the inclusion of literacy $(h)$ in equation (4) explains on average one percentage point per annum of GDP growth over the century. This increase in literacy was concentrated on the mid-century decades, and is associated with urbanization and better access to primary schools (Astorga et al., 2005b).

The sharp increase in participation rates (in other words, the decrease in dependency ratios) in the mid-1970s is evident in Figure 4 when compared with the U.S. or Spain. The increase was mainly due to the lagged effect of declining infant mortality during the 1940s and 1950s as public healthcare improved, but the increase in activity rates starts as early as 1960 in Brazil; around 1970 in Chile, Colombia, Venezuela, and Mexico; and as late as 1990 in Argentina. The entry of women into the workforce as social structures and labor requirements changed was clearly important, with the greatest increases in the female participation rate occurring in Mexico, Venezuela, Brazil, and Colombia-rather than the apparently more "socially advanced" Chile and Argentina. ${ }^{27}$

\footnotetext{
${ }^{26}$ The arithmetic is implacable: a notional economy with a capital-output ratio of 3 and a depreciation rate of 0.05 requires the GFCF/GDP share to be 15 percent just to keep the net capital stock constant. If the work force is growing at 2 percent per annum, this share must be at least 21 percent to prevent the net capital stock per worker from falling.

${ }^{27}$ See Appendix Table A10. This increase in female participation may be due in part to improved recording, particularly as women's participation in agriculture and in family firms has traditionally been high but under-reported in censuses.
} 


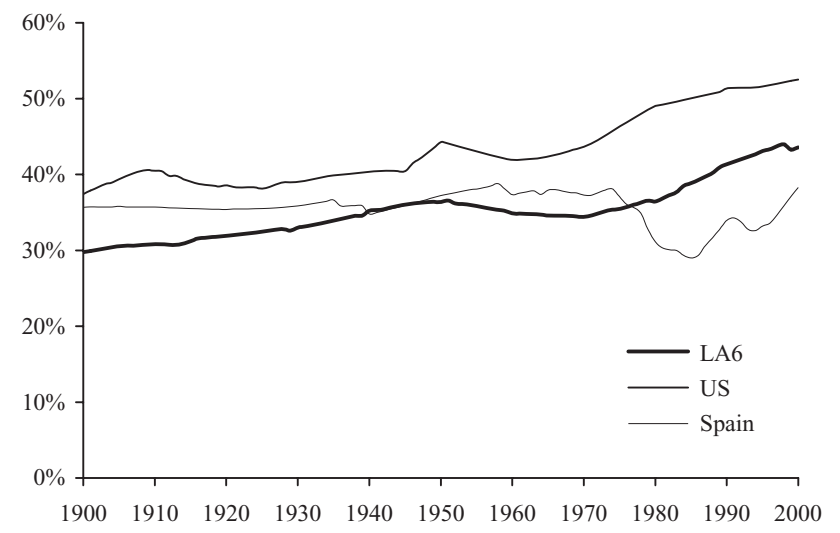

Figure 4. Participation Rates (Workforce/Population) in Latin America 1900-2000 (\%)

Source: Ratio of economically active population to population. Data for LA6 are the population weighted mean from OxLAD; for Spain and U.S. from Maddison (2001); Prados de la Escosura (2003).

\section{Conclusions}

In this paper we have presented what we believe to be the first productivity estimates for Latin America for the twentieth century as a whole, and have identified three statistically distinct periods (1900-36, 1937-77, and 1978-2000) with substantial and sustained productivity growth only observed in the second. This pattern is repeated in all the six major economies of the region, albeit with some minor differences in timing. The only sustained progress was in the middle period of state-led industrialization: the natural resource export-led model of the first three decades of the century involved little productivity growth as did the closing decades, despite extensive economic reforms ${ }^{28}$ Indeed during the opening years of the twenty-first century the low productivity growth trend has continued unabated. ${ }^{29}$

Comparing our results for 1900-79 with those for seven industrial economies in the century 1880-1979 in Wolff (1991) in Table 6, labor productivity growth is broadly similar; but the TFP growth rates are much higher in the latter group. This is partly due to different estimation methods ${ }^{30}$ but the gap is nonetheless striking. Comparing the pre- and post-World War II periods, again the productivity growth is similar, but the Latin American TFP growth is much slower.

In sum, the low levels of investment in fixed and human capital are at the root of the productivity performance in Latin America. However, this statistical

\footnotetext{
${ }^{28}$ In historical terms, the choice of 1900 to start our analysis is arbitrary: it would be desirable to extend the series back toward 1880 when the export-led "liberal" period began, but reliable data are not available. See Cárdenas et al. (2000).

${ }^{29}$ The World Bank (2004) gives GDP/EAP annual growth in the region as only 0.4 percent for 2001-05 and forecasts only 0.7 percent for 2006-15.

${ }^{30}$ Wolff (1991) adjusts for hours worked, which we cannot do; but we use augmented labor (i.e. adjusted for literacy) and Wolff does not. These two adjustments would tend to raise the residual (and thus measured TFP) for Wolff, and lower it for us.
} 
TABLE 6

Comparative Labor and Total Factor Productivity Growth Rates: Industrial Countries AND LATIN AMERICA

\begin{tabular}{lccc}
\hline \hline Latin America & $1900-36$ & $1950-79$ & $1900-79$ \\
\hline Labor productivity & 1.7 & 4.5 & 2.1 \\
Total factor productivity & 0.1 & 0.8 & 0.2 \\
\hline Industrial countries & $1880-1936$ & $1950-79$ & $1880-1979$ \\
\hline Labor productivity & 1.8 & 4.3 & 2.5 \\
Total factor productivity & 0.9 & 2.5 & 1.4 \\
\hline
\end{tabular}

Source: Wolff (1991), Appendix tables.

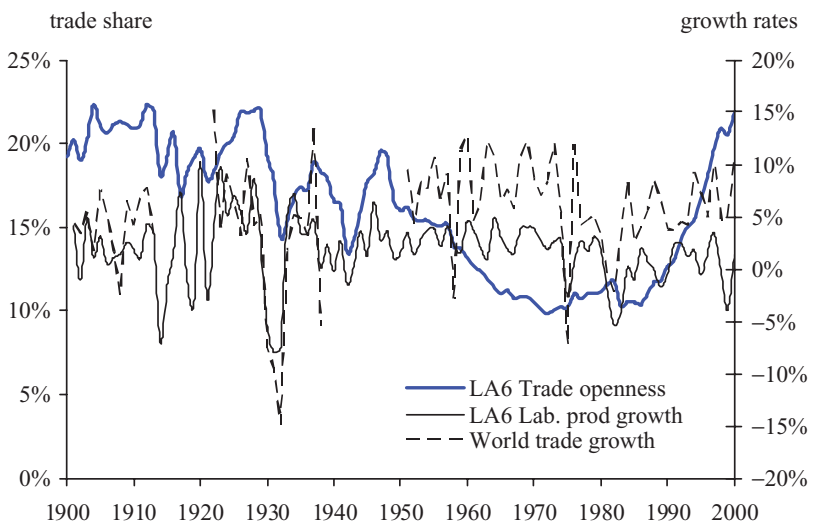

Figure 5. Trade Openness and Growth in the LA6 Plus World Trade

Source and notes: "Trade openness" defined as the average of imports and exports divided by $2 *$ GDP. LA6 data from OxLAD, see Astorga et al. (2003). World trade growth is calculated from and index volume from Findlay and O'Rourke (2007, pp. 505-6).

finding - however significant-leaves undetermined the two rates of factor accumulation themselves. In fact, the three periods we have identified were associated both with distinct economic development strategies and with differing world market circumstances, which it is reasonable to suppose, explain a good part of the observed behavior.

World activity is expected to have a lasting effect on productivity via openness to international trade. However, in the case of twentieth-century Latin America, the growth in the world economy is negatively correlated with trade integration, reflecting the fact that the region adopted an inward-looking strategy during a period of an unprecedented expansion in global trade (see Figure 5). Simple unconditional pair correlations between the volume of world trade (Findlay and O'Rourke, 2007) and labor productivity and TFP growth, respectively, show a relatively weak link, probably due to the business cycle. Moreover, in a panel data regression-where shorter-term influences are minimized, Astorga (2010) found that trade openness was negatively related to labor productivity, although it did have a positive effect on the investment ratio after controlling for relative price 
volatility and the accelerator-principle effect. This suggests that the main impact of integration to the world economy was indirectly via demand (capital accumulation) rather than through competition (efficiency gains).

The relatively more successful $1937-77$ period of faster productivity growth and higher factor accumulation was a typical case of "early" industrialization based on high rates of private investment led by consumer goods supply to protected domestic markets and high rates of public investment led by public provision of economic infrastructure and human capital (health and education). Productivity, and thus incomes, grew much more rapidly than in the previous period of reliance on natural resource exports; reflecting the experience of industrial countries where "TFP catch-up is found to be positively associated with capital:labor growth and strongest when capital intensity is growing most rapidly" (Wolff, 1991, p. 565). It might seem at first sight that the post-World War II upswing (and indeed the 1900-36 record) in Table 6 is merely a reflection of global trends, but this does not explain why rapid growth started as early as the 1940s in Latin America, or why it was lacking after 1980.

The question then is why this was not continued into to a "mature" industrialization stage based on producer goods supply and manufactured exports - except in the case of Mexico, which became integrated to the U.S. economy. The subsequent "neo-liberal" development strategy did not lead to increased productivity growth in the closing decades of the century, as we have seen.

The period of relatively high accumulation in Latin America - although not high by the standards of East Asia - was brought to an end by a growing debt overhang, which caused financial collapse throughout the region in the early 1980s. This then triggered the subsequent policy shift toward trade liberalization, deregulation, and privatization. Some authors attribute this failure to intrinsic problems of the industrialization model itself, particularly protectionist pressures from domestic firms unable to compete on world markets on the one hand and the excessive cost of politically mobilized labor on the other. ${ }^{31}$ However, this crisis was undoubtedly fiscal in origin: it was not brought about by problems of productive efficiency, except in the sense that an industrial export boom would have made the debt easier to service. Indeed, most governments had shifted industrial promotion policies toward exports by the early 1970s and those industrial sectors that did become internationally competitive were in any case established in the previous import-substitution stage (Teitel and Thoumi, 1986; Bruton, 1998). The failure to raise tax levels in order to provide adequate infrastructure and education had its roots in the political economy of inequality (Shome, 1999; FitzGerald, 2001).

In a global economy, productivity growth can no longer be pursued under state direction behind tariff barriers. Latin American economic institutions are now comparable with those in other industrializing countries, but the region still has far lower levels of knowledge provision (particularly secondary education and

\footnotetext{
${ }^{31} \mathrm{On}$ the impact of institutional constraints and populism on the state-led industrialization model, see Katz and Kosacoff (2001) and Dornbusch and Edwards (1991), respectively. Note that productivity began to slow down in 1977-78, before the debt crisis.
} 
research activity) and of infrastructure supply (Paus, 2003). Higher investment (both public and private) is thus as central to increasing productivity growth in this century as it was in the previous one.

\section{REFERENCES}

Astorga, P., "A Century of Economic Growth in Latin America," Journal of Development Economics, 92, 232-43, 2010.

Astorga, P., A. R. Bergés, and E. V. K. FitzGerald, "The Oxford Latin American Economic History Database (OxLAD)," The Latin American Centre, Oxford University, http://oxlad.qeh.ox.ac.uk/, Oxford, 2003.

_. "Endogenous Growth and Exogenous Shocks in Latin America during the XXth Century," Discussion Papers in Economic and Social History, 57, Nuffield College, Oxford University, http://www.nuff.ox.ac.uk/Economics/History/, March 2005a.

- "The Standard of Living in Latin America over the Twentieth Century," Economic History Review, 58, 4, November 2005b.

Barro, R. J. and J-W. Lee, "International Data on Educational Attainment Updates and Implications," NBER Working Papers, 7911, 2000.

Barro, R. J. and X. Sala-i-Martín, Economic Growth, McGraw Hill, New York, 1995.

Baumol, W., "Productivity Growth Convergence and Welfare: What the Long-Run Data Show," American Economic Review, 76, 1072-85, 1986.

Bruton, H. J., "Productivity Growth in Latin America," American Economic Review, 57, 1099-116, 1967.

_ _ "Total Factor Productivity Growth," Williams College Centre for Development Economics Research Memorandum, 139, 1995.

_ "A Reconsideration of Import Substitution," Journal of Economic Literature, 36, 903-36, 1998.

Bulmer-Thomas, V., The Economic History of Latin America since Independence, Cambridge University Press, Cambridge, 1994.

Cárdenas, E., J. A. Ocampo, and R. Thorp (eds), The Export Age: The Latin American Economies in the Nineteenth and Early Twentieth Centuries, An Economic History of Twentieth-Century Latin America, Series 1, Palgrave Macmillan in association with St Antony's College, Basingstoke, 2001.

Collins, S. M. and B. P. Bosworth, "Economic Growth in East Asia: Accumulation Versus Assimilation," Brookings Papers of Economic Activity, 2, 135-203, 1996.

Crafts, N. and T. C. Mills, "TFP Growth in British and German Manufacturing, 1950-1996," Business Cycle Volatility and Economic Growth Research Papers, 1/3, August 2001.

Dahlman, C. J., B. Ross, and L. E. Westphal, "Managing Technological Development: Lessons from the Newly Industrializing Countries," World Development, 15, 759-75, 1987.

De Gregorio, J., "Economic Growth in Latin America," IMF Working Papers, WP/91/71, International Monetary Fund, Washington DC, 1991.

del Popolo, F., "Características Sociodemográficas y Socioeconómicas de las Personas de Edad en América Latina,” Población y Desarrollo, 19, CELADE, Santiago de Chile, 2001.

Dornbusch, R. and S. Edwards (eds), The Macroeconomics of Populism in Latin America, National Bureau of Economic Research Conference Report, University of Chicago Press, Chicago, 1991.

Easterly, W. and R. Levine, "It's Not Factor Accumulation: Stylized Facts and Growth Models," The World Bank Economic Review, 15, 177-219, 2001.

Fajnzylber, P. and D. Lederman, "Economic Reforms and Total Factor Productivity Growth in Latin America and the Caribbean, 1950-95: An Empirical Note," World Bank Policy Research Working Papers, 2114, World Bank, Washington DC, 2000.

Findlay, R. and K. H. O'Rourke, Power and Plenty: Trade, War, and the World Economy in the Second Millennium, Princeton University Press, 2007.

Fischer, S., "The Role of Macroeconomic Factors in Growth," Journal of Monetary Economics, 32, 485-512, 1993.

FitzGerald, E. V. K., The Macroeconomics of Development Finance, Macmillan Press, Basingstoke, 1993.

, "Restructuring through the Depression: The State and Capital Accumulation in Mexico, 1925-40," in Rosemary Thorp (ed.), Latin America in the 1930s: The Role of the Periphery in World Crisis, An Economic History of Twentieth-Century Latin America, Series 2, Palgrave Macmillan in association with St Antony's College, Basingstoke, 2000.

, "ECLA and the Theory of Import-Substituting Industrialisation in Latin America," in E. Cárdenas, J. A. Ocampo, and R. Thorp (eds), Industrialisation and the State in Latin America, An 
Review of Income and Wealth, Series $\bullet$, Number $\bullet \cdot, \bullet 2011$

Economic History of Twentieth-Century Latin America, Series 3, Palgrave Macmillan in association with St Antony's College, Basingstoke, 2001.

Goldsmith, R. W., "A Perpetual Inventory of National Wealth," in M. R. Gainsburgh (ed.), Studies in Income and Wealth, Princeton University Press, Princeton, 1951.

Grossman, G. M. and E. Helpman, "Endogenous Innovation in the Theory of Growth," Journal of Economic Perspectives, 8, 23-44, 1994.

Hofman, A., The Economic Development of Latin America in the Twentieth Century, Edward Elgar, Cheltenham, 2000.

ILO (International Labour Office), LABORSTA On-Line, International Labour Office, 2002.

IMF (International Monetary Fund), International Financial Statistics, IMF, Washington DC, 2002.

Katz, J. and B. Kosacoff, "Technological Learning, Institution Building and the Microeconomics of Import Substitution," in E. Cárdenas, J. A. Ocampo, and R. Thorp (eds), Industrialisation and the State in Latin America, An Economic History of Twentieth-Century Latin America, Series 3, Palgrave Macmillan in association with St Antony's College, Basingstoke, 2001.

Maddison, A., Monitoring the World Economy, 1920-1992, Organisation for Economic Co-operation and Development, Paris, 1995.

- The World Economy: A Millennial Perspective, Organisation for Economic Co-operation and Development, Paris, 2001.

Mankiw, N. G., D. Romer, and D. N. Weil, "A Contribution to the Empirics of Economic Growth," Quarterly Journal of Economics, 107, 407-37, 1992.

Martin, W. and D. Mitra, "Productivity Growth and Convergence in Agriculture and Manufacturing," Economic Development and Cultural Change, 49, 403-22, 2001.

Mulder, N., Economic Performance in the Americas: The Role of the Service Sector in Brazil, Mexico and the USA, Elgar, Aldershot, 2002.

Nehru, V. and A. M. Dareshwar, "A New Database on Physical Capital Stock: Sources, Methodology and Results," Revista de Análisis Económico, 8, 37-59, 1993.

North, D. C., "Institutions and Productivity in History," Washington University Economic History Papers, 9411003

Paus, E. P., "Productivity Growth in Latin America: The Limits of Neoliberal Reforms," World Development, 32, 427-45, 2003.

Prados de la Escosura, L., El Progreso Económico de España, 1850-2000, Fundación BBVA, Madrid, 2003.

Pritchett, L., "Mind Your P's and Q's: The Cost of Public Investment Is Not the Value of Public Capital," World Bank Policy Research Working Papers, 1660, World Bank, Washington DC, 1996.

Romer, P. M., "Human Capital and Growth: Theory and Evidence," Carnegie-Rochester Conference Series on Public Policy, 32, 251-86, 1990.

, "Idea Gaps and Object Gaps in Economic Development," Journal of Monetary Economics, 32, 543-73, 1993.

Scott, M. F. G., A New View of Economic Growth, Clarendon Press, Oxford, 1991.

Solimano, A., "Economic Growth under Alternative Development Strategies: Latin America from the 1940s to the 1990s," in A. Solimano (ed.), Road Maps to Prosperity: Essays on Growth and Development, University of Michigan Press, Ann Arbor, 1996.

Teitel, S. and F. Thoumi, "From Import Substitution to Exports: The Manufacturing Experience of Argentina and Brazil," Economic Development and Structural Change, 34, 455-90, April 1986.

Thorp, R., Progress, Poverty, and Exclusion: An Economic History of Latin America in the 20th Century, Inter-American Development Bank, 1998.

Wolff, E., "Capital Formation and Productivity Convergence Over the Long Term," American Economic Review, 81, 565-79, 1991.

World Bank, Global Economic Prospects 2005, World Bank, Washington DC, 2004.

Young, A., "Lessons from the East Asian NICs: A Contrarian View," European Economic Review, 38, 964-73, 1994.

, "The Tyranny of Numbers: Confronting the Statistical Realities of the East Asian Growth Experience," Quarterly Journal of Economics, 110, 641-80, 1995.

\section{SUPPORTING INFORMATION}

Additional Supporting information may be found in the online version of this article:

Figure A1. Sectoral Productivity in Latin America 1900-2000 (1970 PPP\$ per EAP)

Figure A2. Capital Stock per EAP in Latin America

(C) 2011 The Authors

Review of Income and Wealth (C) International Association for Research in Income and Wealth 2011 
Table A1. Output per Worker (1970 PPP\$)

Table A2. PPP Adjustment of GDP

Table A3. Sectoral Productivity, EAP and GDP Shares

Table A4. Sectoral Productivity Growth Rates by Decade

Table A5. Coefficients and Diagnostics for TFP Model

Table A6. Period Averages of TFP Growth (\%): Standard Coefficients

Table A7(A). Decennial Average TFP Growth Rates (\%)

Table A7(B). Decennial Average TFP Growth Rates (\%)

Table A8. Investment Share of GDP, 1900-2000 (\%)

Table A9. Literacy Rates (\%)

Table A10. Female Participation in the Economically ACTIVE Population (\%)

Table A11. Physical Capital Stock, 1900-2000 (Thousand 1970 PPP\$)

Please note: Wiley-Blackwell are not responsible for the content or functionality of any supporting materials supplied by the authors. Any queries (other than missing material) should be directed to the corresponding author for the article. 